\title{
Pedological Characterization of Typical Soils of Dodoma Capital City District, Tanzania: Soil Morphology, Physico-chemical Properties, Classification and Soil Fertility Trends
}

\author{
Balthazar M. Msanya ${ }^{1 *}$, Tumaini A. Mwasyika ${ }^{2}$, Nyambilila Amuri ${ }^{1}$, Ernest Semu ${ }^{1}$ and Lydia Mhoro ${ }^{1}$ \\ ${ }^{1}$ Department of Soil and Geological Sciences, College of Agriculture, Sokoine University of Agriculture, Box 3008, \\ Morogoro, Tanzania \\ ${ }^{2}$ Department of Water Resources and Irrigation Engineering, Water Institute, P.O. Box 35059 Dar es Salaam, \\ Tanzania \\ *Email: bmmsanya@gmail.com
}

\begin{abstract}
Pedolological characterization was done in Dodoma Capital City District, Tanzania. Three soil profiles developed from in-situ weathering of granic rocks and designated as HIS-P1, HISP2 and HIS-P3 were described. Fifteen samples were taken from genetic horizons and analyzed for physical and chemical characteristics. The soils were generally very deep, with varying textures. Whereas profile HIS-P2 was dominantly loamy, profiles HIS-P1 and HIS-P3 were both clayey but the latter had heavy clay type. In profile HIS-P1, clay eluviation-illuviation was a dominant pedogenic process manifested by presence of clay cutans in the subsoil. Profile HIS-P2 displayed redoximorphic features due to fluctuating water table. Shrinking and swelling, and argilli-pedoturbation were typical pedogenic processes in profile HIS-P3. Profile HIS-P1 had more developed structure (subangular blocky) followed by HIS-P3 and lastly profile HIS-P2 which was structureless massive breaking into weak subangular blocks. Whereas topsoil bulk density values of the soils were within acceptable range, subsoil BD values are likely to cause problems of root penetration particularly for deep rooted crops. Profiles HIS-P1 and HIS-P3 may present limitations to crop growth due to high pH values (> $7.5)$ in the subsoil which may limit availability of plant nutrients e.g. phosphorus. Organic carbon and nitrogen were generally low and very low in all profiles with most values being $<1.25 \%$ and $<$ $0.10 \%$, respectively. Availabe $\mathrm{P}$ values were low to very low $(<7 \mathrm{mg} / \mathrm{kg})$ throughout the three profiles. Topsoil base saturation values were high $(>50 \%)$ in profiles HIS-P1 and HIS-P2 but very high throughout proflie HIS-P3 $(83-118 \%)$. Zn and Fe levels were rated as inadequate for crop production. According to USDA Soil Taxonomy, the soils were classified as Typic Rhodustults (HISP1), Fluventic Dystrustepts (HIS-P2) and Chromic Calcitorrerts (HIS-P3) corresponding to Haplic Cutanic Acrisols, Haplic Cambisols and Calcic Mazic Vertisols in the WRB for Soil Resources. The three soils had different physico-chemical properties, hence the need to characterize soils before fertilizer recommendations is met.
\end{abstract}

Keywords: Soil morphology and genesis; physical properties; chemical properties; soil classification; Dodoma, Tanzania

\section{Introduction}

Pedological information is important to land users especially farmers who use the data to make decisions on what crops and management practices are best for optimal and sustainable crop production. According to [1], pedological studies and land resource surveys provide a good understanding of spatial changes in the characteristics of the soil continuum so that soils may be used more efficiently for the benefit of mankind. Collecting soil information through systematic soil survey is a prudent way of registering the holistic picture about the behaviour of soils of an area and requires knowledge about soil morphology, genesis, properties and classification [2]. Soil and related land resources inventory data are basic in guiding and enabling forecast of land use potential and management requirements for sustained agricultural production [2]. In ecological studies, soil and land resource surveys provide geographical information or spatial soils information which can be used to correlate with vegetation data to obtain 
more complex picture of a given ecosystem [3]. Thus, pedological characterization is a pre-requisite for sustainable soil management and proper use of soil resources [4].

Pedological characterization provides data and knowledge on soil properties and related site characteristics [5]. The aim of pedological characterization is to know potentials and limitations of soils to enable planning for different uses [6]. On the other hand, the term "land resources characterization" is used to imply all organized and systematic activities and procedures done in the field, laboratory and office aiming at generating data and other relevant information about the characterized land [7].

Soils are formed through the interaction of five major factors: parent material, topography and climate, organisms and time. The relative influence of each factor varies from place to place, but the combination of all five factors normally determines the kind of soil developing in a given place [8]. Soils are defined in terms of these factors as dynamic natural bodies having properties derived from the combined effect of climate and biotic activities (organisms), as modified by topography, acting on parent materials over periods of time [5]. As soils form, nutrients are being continually removed and added to the soil with time and the conditions of soil formation ultimately determine the amount and kind of nutrients the soil can naturally supply and hold [9].

The soil survey carried out in Dodoma Capital City District [10] was of reconnaissance scale. This work at a scale of 1:50,000 described the soils of Dodoma Capital District generally as soils of a variety of textures, ranging from coarse sands to heavy clays. Most soils have poor vegetation cover and low nutrient status especially with respect to $\mathrm{N}, \mathrm{P}$ and $\mathrm{Zn}$. Organic matter contents are very low; also the structural properties of the Dodoma Capital District soils are poor. The soils are susceptible to erosion and since the vegetative cover is poor, topsoils have been eroded, whereby the exposed surfaces become very hard when dry giving the false impression of hardpans [10].

Much as the work of [10] may be useful for planning at district level, it may not be adequate for planning at village or farm level. The scale of mapping soils was quite coarse and field work was very limited. In view of this, there was a need to characterize soils and related land resources through the current study, to obtain adequate information for sound land use planning. Moreover, soil fertility specialists need well characterized soils and well defined ecological conditions in order to carry out meaningful fertilizer trials to enhance transferability of information from one place to another [11]. The current study is an attempt to enrich the knowledge and database on the soils and related land resources of Dodoma area. In so doing, it will allow land users particularly farmers and agricultural researchers to make proper decisions on what crops and management practices are best for the various soils of the area. The main objective of the study was to characterize the soils of the study area in terms of their morphological and physico-chemical properties and fertility status, and classify them using the USDA Soil Taxonomy [12] and the World Reference Base for Soil Resources [13].

\section{Materials and Methods}

\subsection{Geographical Setting, Relief and Climate}

This study was carried out in Dodoma Capital City District, Dodoma Region in the central zone of Tanzania. Dodoma city lies between longitudes $35^{\circ} 30^{\prime}$ and $36^{\circ} 10^{\prime} \mathrm{E}$ and between latitudes $5^{\circ} 50^{\prime}$ and $6^{\circ}$ $30^{\prime} \mathrm{S}$ and has an altitude ranging between 1400 and 2800 m.a.s.l. The area can be broadly described as a plateau, with an overall eastward slope and low relief intensity. The main physiographic features of Dodoma include mountains, inselbergs and hills, footslopes, lowland plains, intermediate plains, lakes, river valleys, escarpments, drainage and water resources. The area falls under semi-arid climate, receiving a total annual rainfall ranging between 395 and $780 \mathrm{~mm}$. Rainfall distribution is mono-modal and starts in late November, reaches a peak in December/January and ends in April [14]. In February/March the district often experiences a long dry spell during the growing season, which sometimes can last for 40 days. The dry season in this district lasts for typically six months, starting in May and ending in early November. The monthly maximum and minimum temperatures are about $29.6^{\circ} \mathrm{C}$ in February and $17.6^{\circ} \mathrm{C}$ in July, respectively [14, 15]. Figure 1 presents some climatic data of the study area. 


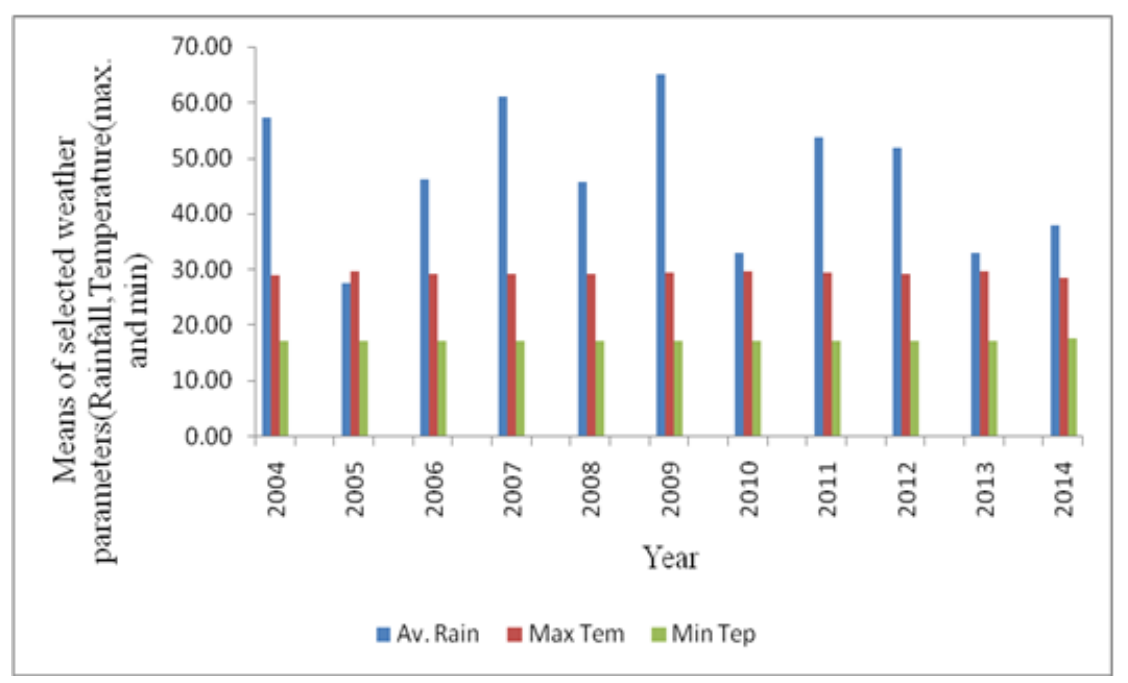

Figure 1. Climate data for Dodoma Capital City District, Tanzania (Average rainfall, maximum temperature and minimum temperature) against year.

\subsection{Geology of Dodoma Capital City District}

The geology of the study area is underlain by intrusive Basement Complex rocks, mainly granites. The granitic rocks enclose disconnected fragments of older Basement rocks, belonging to the Dodoma Formation and are believed to be of late Precambrian age [16]. In addition, basic and ultrabasic intrusive rocks may occur as younger dykes, penetrating the granites. The most common granitic rocks are grey, non-schistose and rarely porphyritic granites. Near to the older basic rocks there is evidence of an enrichment of dark minerals as well as an abundance of streaks and bands of dark schists. The Basement Complex rocks are covered by a mantle of loose or cemented superficial deposits of alluvial, colluvial and residual origin and of Tertiary or Quaternary age. The cemented superficial deposits include argillaceous or calcareous cements. The argillaceous cements have high clay content and are characteristically very hard and compact when dry, but soft when moist. The cementing material is largely calcareous and the abundance of calcium is probably due to the persistence of the sites as freshwater swamps until the present day [10]. Several of these calcareous deposits underlie the black clays of the lowland plains west of the Hombolo escarpment and are exploited as a source of building lime. The loose superficial deposits include most of the present-day soils and are formed by residual weathering. The sub-recent tectonic movements related to East African Rift Valley are visible in the landscape which has the general appearance of a warped plateau gently sloping to the East [16].

\subsection{General Overview of Soils of Dodoma Capital City District}

The soils of Dodoma differ due to the geological formation or parent materials forming the soils and the relief of the area [10]. Reddish clayey soils occur on the footslopes of basic metamorphic hills of the Dodoma Formation while reddish loamy soils occur on the footslopes of granitic hills. Wherever granite has been contaminated by basic inclusions of the Dodoma Formation, more reddish and clayey soils may be present. Reddish loamy or clayey soils are also associated with fault or shear zones within the basement complex. Such zones with red soils are common on the upland plains and along the escarpments. Brown loamy and sandy soils occupy the better drained parts of the upland plains. These areas are also characterized by the omni-presence of eroded or vegetated termite mounds. Dark, sticky, cracking clays and friable, calcareous clays occupy the poorer drained parts of the area, such as the lowland plains and the swamps. A brownish or reddish loamy colluvium overlies gray heavy alluvium in the river valleys. The colluvium originates mainly from the Dodoma Hills and appears to be the result of accelerated erosion in the area. All soils of Dodoma are of low nutrient status and low organic matter content, due to the granitic parent materials and low vegetation cover [10]. 


\subsection{Vegetation and Land Use of Dodoma Capital City District}

According to the physiognomic classification of [17], the most predominant natural vegetation types include woodland ( $0.5 \%$ of the area), bushland (about 50\%), wooded bushland/grassland (15\%), pure grassland (5\%), and permanent swamp vegetation (15\%). It appears that the woodland was probably much more extensive in the past and it is likely that its regeneration is prohibited by present overgrazing and cultivation practices in various physiographic units. The main land use types are production of crops such as sorghum, finger millet, maize, grapes and vegetables which are more extensive land use types than grazing [10]. Tomatoes and vegetables are successfully grown by handirrigation from nearby river beds. About $70 \%$ of the area is used for seasonal crop production and grazing may occur on fallow land, but it is usually not integrated with arable farming. Fodder is scarce and overgrazing is the rule rather than the exception. Cultivation is mainly concentrated near the river valleys where seasonal water tables provide additional moisture to supplement the low and variable rainfall. Generally, the agricultural land is of short supply (average 1.5 ha per family) and is considered of inferior status due to drought and persistent risk of crop failure. Thus, farmers reduce fallow periods below optimal levels and in the long run this situation may lead to exhaustion of the land and soil and vegetation degradation. This is already evidenced by the spectacular soil erosion in the once productive foot slopes of the Dodoma Hills, which are now gullied wastelands unsuitable for cultivation [9].

\subsection{Agro-ecological Zones of the Study Area}

The agro-ecological zones of Dodoma are mainly influenced by land morphology/relief. The major agroecological zones include the mountains, the upland plains, lowland plains and intermediate plains. The current study was conducted in the lowland plains, which are dependable for agricultural production. The lowland plains cover the less well drained parts of the plateau, probably originating from a former lake bottom [10]. The lowland plains have very low relief intensity and are virtually un-dissected or affected by erosion. Typical slopes are less than 1\%. The soils of the lowland plains are heavy cracking black clays, or non-cracking brown clays, often saline and sodic. The natural vegetation is grassland or bushed grassland. Lowland plains of the Dodoma Capital City District cover about 115 sq. km [10].

\subsection{Pedological Characterization in Dodoma Capital City District}

Field Methods.

Reconnaissance survey was done in Hombolo Irrigation scheme using transect walks and soil augering to delineate sampling units based on the land morphology and orientation, soil physical attributes, cropping systems and vegetation. In each identified sampling unit, soil observations were made to a maximum depth of $1.5 \mathrm{~m}$ or to a limiting layer to identify soil properties by augering along the transect. Based on the information obtained from free reconnaissance survey, a total of 3 soil profile pits representing the dominant physiographic units in the study area were selected and fully geo-referenced. The three profiles were located within the Hombolo Irrigation Scheme (HIS) and represent the major agricultural soils in Hombolo and Ihumwa areas. Soil profile pits were dug to a depth of $2 \mathrm{~m}$ or to a lithic or paralithic contact.

Table 1. Salient characteristics of the studied sites in Dodoma Capital City District, Tanzania

\begin{tabular}{|c|c|c|c|c|c|c|c|c|c|}
\hline Profile & Geology /lithology & $\begin{array}{l}\text { AEZ } \\
\text { code }\end{array}$ & Coordinates & $\begin{array}{l}\text { Altitude } \\
(\mathrm{m})\end{array}$ & $\begin{array}{l}\text { Rainfall } \\
\text { mm/year }\end{array}$ & Landform & Land use & STR & SMR \\
\hline HIS-P1 & $\begin{array}{l}\text { Pre-Cambrian rocks of basement } \\
\text { complex, mainly granites }\end{array}$ & ${ }^{*} \mathrm{LL}$ & $\begin{array}{l}035^{\circ} 59^{\prime} 35.2^{\prime \prime} \mathrm{E} \\
05^{\circ} 57^{\prime} 23.3^{\prime \prime} \mathrm{S}\end{array}$ & 1039 & $500-570$ & $\begin{array}{l}\text { plateau/ } \\
\text { peneplane }\end{array}$ & $\begin{array}{l}\text { Agriculture } \\
\text { under irrigation }\end{array}$ & $\begin{array}{l}\text { Isohyper- } \\
\text { thermic }\end{array}$ & $\begin{array}{l}\text { Aridic- } \\
\text { Ustic }\end{array}$ \\
\hline HIS-P2 & -as above- & -as above- & $\begin{array}{l}035^{\circ} 59^{\prime} 48.0^{\prime \prime} \mathrm{E} \\
05^{\circ} 58^{\prime} 23.4^{\prime \prime} \mathrm{S}\end{array}$ & 1039 & $500-570$ & $\begin{array}{l}\text { plateau/ } \\
\text { peneplane }\end{array}$ & Agriculture & -as above- & $\begin{array}{l}\text { Aridic- } \\
\text { Aquic }\end{array}$ \\
\hline HIS-P3 & -as above- & -as above- & $\begin{array}{l}035^{\circ} 59^{\prime} 39.9^{\prime \prime} \mathrm{E} \\
05^{\circ} 57^{\prime} 55.1^{\prime \prime} \mathrm{S}\end{array}$ & 1024 & $500-570$ & $\begin{array}{l}\text { plateau/ } \\
\text { peneplane }\end{array}$ & Agriculture & -as above- & $\begin{array}{l}\text { Aridic- } \\
\text { Ustic }\end{array}$ \\
\hline
\end{tabular}

N.B. ${ }^{*} \mathrm{LL}=$ Low Land, $\mathrm{STR}=$ Soil temperature regime, $\mathrm{SMR}=$ Soil moisture regime, $\mathrm{AEZ}=$ Agro-ecological zone 
The soil profiles namely HIS-P1, HIS-P2 and HIS-P3 were studied and described according to FAO Guidelines for Soil Description [18]. In each profile pit, disturbed composite samples were taken from each horizon for physical and chemical analysis in the laboratory. A total of fifteen samples representing pedogenic horizons of the three profiles were collected. Table 1 gives a summary of the pertinent features of the study sites.

Laboratory Methods.

Disturbed composite soil samples were used for determination of physical and chemical properties of soils. Particle size analysis was determined by hydrometer method after dispersion with $5 \%$ sodium hexametaphosphate [19]. Textural classes were determined using USDA textural triangle [20]. Soil pH was measured potentiometrically in water and $1 \mathrm{~N} \mathrm{KCl}$ at a ratio of 1:2.5 soil:water and soil:KCl [21]. Organic carbon was determined by Walkley and Black wet oxidation method [22]. Organic carbon obtained was converted to organic matter by multiplying by a factor of 1.724 [23]. Total $\mathrm{N}$ was determined using micro-Kjeldahl digestion-distillation method as described by [24]. Available phosphorus was determined using filtrates extracted by Bray and Kurtz-1 method [25] and determined by spectrophotometer at $884 \mathrm{~nm}$ following colour developed by Molybdenum blue method [26, 27]. Extractable micronutrients $(\mathrm{Fe}, \mathrm{Zn}, \mathrm{Cu}$ and $\mathrm{Mn}$ ) were determined by diethylenetriaminepentaacetic acid (DTPA) in a mixture of $0.01 \mathrm{M} \mathrm{CaCl} 2$ and $0.1 \mathrm{M}$ Triethanolamine (TEA) buffered at $\mathrm{pH} 7.3$, and determined by Atomic absorption spectrophotometer [28]. Cation exchange capacity of soil $\left(\mathrm{CEC}_{\text {soil }}\right)$ and exchangeable bases were determined by saturating soil with neutral 1M NH4OAc (ammonium acetate) and the adsorbed $\mathrm{NH}_{4}^{+}$was displaced by using $1 \mathrm{M} \mathrm{KCl}$ and then determined by Kjeldahl distillation method for estimation of CEC of soil [29]. Cation exchange capacity of clay $\left(\mathrm{CEC}_{\text {clav }}\right)$ was calculated using the formula outlined by [30] which corrects for the CEC contributed by organic matter (OM) as follows:

$$
\mathrm{CEC}_{\text {clay }}=\left(\left\{\mathrm{CEC}_{\text {soil }}-\left(\% \mathrm{OM}^{*} 2\right)\right\} / \% \text { clay }\right) * 100
$$

Exchangeable bases $\left(\mathrm{Ca}^{2+}, \mathrm{Mg}^{2+}, \mathrm{Na}^{+}\right.$and $\left.\mathrm{K}^{+}\right)$were determined by atomic absorption spectrophotometer [31]. Total exchangeable bases (TEB) were calculated arithmetically as the sum of the four exchangeable bases for a given soil sample. Electrical conductivity was determined in 1:2.5 soil:water suspension using an electrical conductivity meter as per method described by [32]. Other parameters which were calculated include $\mathrm{C} / \mathrm{N}$ ratio and percent base saturation (BS \%).

Classification of Soils of Dodoma Capital City District.

Using field and laboratory analytical data, the studied soils were classified to family level of the USDA Soil Taxonomy [12] and toTier-2 of the FAO World Reference Base for Soil Resources [13].

\section{Results and Discussion}

\subsection{Soil Morphology and Genesis}

Some key morphological properties of the studied soils are presented in Table 2. The soils were very deep $(>150 \mathrm{~cm})$ and well drained except soil profile HIS-P3 in which water table was observed around $170 \mathrm{~cm}$. Profile HIS-P1 had distinctly dark reddish brown topsoil over dark red and red subsoil, whereas profile HIS-P2 had very dark gray topsoil over yellowish brown and dark yellowish brown subsoil and profile HIS-P3 dark gray topsoil overlying dark gray to very dark gray subsoil. Profiles HIS-P1 and HISP2 generally had friable to very friable moist consistence, while profile HIS-P3 had very hard consistence particularly in the subsoil. The very hard consistence in profile HIS-P1 is likely to restrict both root growth of most plant/crop species and water flow [33]. Topsoil structures of the three profiles were all crumby. On the other hand, subsoil structures varied widely whereby they were dominantly subangular blocky for profile HIS- P1, structure-less massive for profile HIS-P2 and coarse wedge-shaped structure for profile HIS- P3. The compact coarse wedge-shaped structure in the subsoil of profile HIS-P3 may likely restrict root growth particularly of deep-rooted crops and limit water movement in the profile [33]. Clay cutans were observed in the subsoil of profile HIS-P1 manifesting the occurrence of eluviationilluviation process in this soil. There were abundant medium to coarse, prominent, yellowish red to red mottles in some $\mathrm{C}$ horizons of profile HIS-P2. Moreover, the same profile contained many, medium, hard, round $\mathrm{Fe}$ concretions/nodules. The occurrence of redoximorphic features in form of mottles and $\mathrm{Fe}$ concretions/nodules in this profile may be attributed to redox conditions in the profile resulting from 
fluctuating water table. Hence, reduction and oxidation processes alternately take place in this profile. Similar observations were made elsewhere in Tanzania for similar soils by [34] and [35]. In profile HISP3 prominent shiny slickensides and deep wide cracks were observed. These features together with the prominence of wedge-shaped structure in the subsoil affirm that shrinking and swelling, and pedoturbation (in particular argilli-pedoturbation) were typical pedogenic processes in this profile [34]. Soil horizon boundaries were quite variable, ranging dominantly from gradual to diffuse smooth in soil profile HIS-P1 to clear and diffuse smooth in soil profiles HIS-P2 and HIS-P3.

Table 2. Some morphological characteristics of the studied soils of Hombolo Irrigation Scheme, Dodoma Capital City District, Tanzania

\begin{tabular}{|c|c|c|c|c|c|c|c|}
\hline $\begin{array}{l}\text { Profile } \\
\text { no. }\end{array}$ & Horizon & $\begin{array}{l}\text { Depth } \\
(\mathrm{cm})\end{array}$ & Moist color ${ }^{1}$ & Consinstence $^{2}$ & Structure $^{3}$ & $\begin{array}{l}\text { Other key } \\
\text { pedogenic } \\
\text { features }^{4}\end{array}$ & $\begin{array}{l}\text { Horizon } \\
\text { Boundary }^{5}\end{array}$ \\
\hline \multirow[t]{6}{*}{ HIS-P1 } & Ap & $0-14 / 20$ & $\operatorname{drb}(2.5 \mathrm{YR} 2.5 / 4)$ & $\mathrm{HA}, \mathrm{fr}, \mathrm{s} \& \mathrm{p}$ & $\mathrm{m}, \mathrm{f}-\mathrm{c}$ sbk, $\mathrm{m}, \mathrm{m}, \mathrm{cr}$ & - & $\mathrm{c} / \mathrm{w}$ \\
\hline & $\mathrm{BA}$ & $14 / 20-42$ & $\mathrm{dr}(2.5 \mathrm{YR} 3 / 6)$ & SHA-HA, fr, s \& p & $\mathrm{w}-\mathrm{m}, \mathrm{f}+\mathrm{m}, \mathrm{sbk}$ & - & $\mathrm{g}-\mathrm{d} / \mathrm{s}$ \\
\hline & Bt1 & $42-70$ & $\mathrm{dr}(2.5 \mathrm{YR} 3 / 6)$ & SHA,fr, ss \& sp & $\mathrm{w}-\mathrm{m}, \mathrm{f}+\mathrm{m}, \mathrm{sbk}$ & - & $\mathrm{g}-\mathrm{d} / \mathrm{s}$ \\
\hline & Bt2 & $70-103$ & $\mathrm{dr}(2.5 \mathrm{YR} 3 / 6)$ & SHA-HA, fr, ss \& sp & $\mathrm{m}, \mathrm{m}+\mathrm{f}, \mathrm{sbk}$ & - & $\mathrm{g}-\mathrm{d} / \mathrm{s}$ \\
\hline & Bt3 & $103-137$ & $\mathrm{r}(2.5 \mathrm{YR} 4 / 8)$ & vfr, ss \& sp & $\mathrm{m}-\mathrm{c}, \mathrm{sbk}$ & - & $\mathrm{a} / \mathrm{s}$ \\
\hline & $\mathrm{BC}$ & $137-170+$ & $\mathrm{r}(2.5 \mathrm{YR} 4 / 8)$ & vfr, s \& p & $\mathrm{m}, \mathrm{f}, \mathrm{sbk}$ & - & - \\
\hline \multirow[t]{5}{*}{ HIS-P2 } & Ap & $0-12$ & $\operatorname{vdg}(10 \mathrm{YR} 3 / 1)$ & SHA,fr, ss \& sp & $\mathrm{m}, \mathrm{f}+\mathrm{m}, \mathrm{cr}$ & - & $\mathrm{c} / \mathrm{s}$ \\
\hline & $\mathrm{C} 1$ & $12-35$ & yb (10YR5/4) & HA,fi, ss \& sp & massive, w-m, sbk & - & $\mathrm{c} / \mathrm{s}$ \\
\hline & $\mathrm{C} 2$ & $35-75$ & dyb (10YR4/4) & vfr, ss \& sp & massive., w-m, sbk & - & $\mathrm{c} / \mathrm{s}$ \\
\hline & C3g1 & $75-137$ & yb (10YR5/4) & vfr,ss \& sp & massive, w-m,sbk & mmps-yr & $\mathrm{c} / \mathrm{s}$ \\
\hline & $\mathrm{C} 4 \mathrm{~g} 2$ & $137-190+$ & br(10YR5/3) & fr-fi, ss \& sp & massive, w-m, sbk & amps-r & - \\
\hline \multirow[t]{4}{*}{ HIS-P3 } & Ap & $0-10$ & $\operatorname{dg}(10 \mathrm{YR} 4 / 1)$ & SHA, s \& p & $\mathrm{m}, \mathrm{m}, \mathrm{sbk}, \mathrm{m}, \mathrm{m}, \mathrm{cr}$ & - & $\mathrm{c} / \mathrm{s}$ \\
\hline & B & $10-71$ & dg (10YR4/1) & VHA, vs \& vp & $\mathrm{co}, \mathrm{m}-\mathrm{c}$ wsb & pss; dwc & $\mathrm{d} / \mathrm{s}$ \\
\hline & $\mathrm{Bk}$ & $71-135$ & $\operatorname{vdg}(10 \mathrm{YR} 3 / 1)$ & VHA, vs \& vp & $\mathrm{co}, \mathrm{m}-\mathrm{c}$ wsb & pss; dwc & $\mathrm{a} / \mathrm{s}$ \\
\hline & $\mathrm{Ck}$ & $135-160+$ & pb(10YR6/3) & n.d. & n.d. & - & - \\
\hline
\end{tabular}

Soil profiles: HIS-P1 = Hombolo Irrigation Scheme Profile 1; HIS-P2 = Hombolo Irrigation Scheme Profile 2; HISP3 = Hombolo Irrigation Scheme Profile 3; n.d. = not determined

${ }^{1}$ Soil color: $\mathrm{g}=$ gray; $\mathrm{dg}=$ dark gray; $\mathrm{vdg}=$ very dark gray; $\mathrm{pb}=$ pale black; $\mathrm{dgb}=$ dark gray brown; lyb =light yellowish brown; $\mathrm{yb}=$ yellowish brown; dyb $=$ dark yellowish brown; $\mathrm{br}=$ brown; $\mathrm{b}=$ pale brown; $\mathrm{drb}=$ dark reddish brown; $\mathrm{r}=$ red; $\mathrm{dr}=$ dark red.

${ }^{2}$ Consistence: $\mathrm{fr}=$ friable; vfr $=$ very friable; $\mathrm{s}=$ sticky; $\mathrm{ss}=$ slightly sticky; $\mathrm{vs}=$ very sticky; $\mathrm{p}=$ plastic; $\mathrm{sp}=$ slightly plastic; vp = very plastic; HA = Hard, SHA = slightly hard, SHA - HA = slightly hard to hard, and VHA $=$ very hard

${ }^{3}$ Soil structure: $\mathrm{m}, \mathrm{f}-\mathrm{c} \mathrm{sbk}=$ moderate to coarse subangular blocky; $\mathrm{m}, \mathrm{m}, \mathrm{cr}=$ moderate medium crumby; $\mathrm{w}-\mathrm{m}, \mathrm{f}+\mathrm{m}$, $\mathrm{sbk}=$ weak to moderate fine and medium subangular blocky; $\mathrm{m}, \mathrm{m}, \mathrm{sbk} \& \mathrm{ab}=$ moderate, medium subangular \& angular blocky; mass. $>\mathrm{w}-\mathrm{m}, \mathrm{sbk}=$ massive breaking into weak medium subangular blocky;co, $\mathrm{m}-\mathrm{c}$ wsb $=$ compact medium to coarse wedge-shaped blocks

${ }^{4}$ Mottles: mmps-yr $=$ many medium prominent sharp, yellowish red; amps-r: abundant medium prominent sharp, red

Slickensides: pss $=$ prominent shiny slickensides; Cracks: dwc $=$ deep wide cracks

${ }^{5}$ Horizon boundary: $\mathrm{a}=$ abrupt; $\mathrm{c}=$ clear; $\mathrm{g}=$ gradual; $\mathrm{s}=$ smooth; $\mathrm{w}=$ wavy; gw $=$ gradual wavy; $\mathrm{ds}=$ diffuse smooth; aw $=$ abrupt wavy; $\mathrm{cw}=$ clear wavy; $\mathrm{dw}=$ diffuse wavy.

\subsection{Soil Physical Properties}

\section{Particle Size Distribution.}

Laboratory data on particle size distribution and textural classes of the studied soils are presented in Table 3. Soil texture is the most stable physical characteristic which influences several other soil properties such as soil structure, water and nutrient retention, and nutrient leaching in the soil [39]. The 
topsoil clay contents of the studied soils ranged from 27 to $47 \%$ while subsoil contents ranged from 25 to $72 \%$. Whereas profile HIS-P1 had sandy clay loam topsoil overlying sandy clay subsoil, profile HIS-P2 had sandy clay loam topsoil over sandy clay and sandy clay loam subsoil, and profile HIS-P3 had clay topsoil over heavy clay subsoil. There was a general trend of clay increasing with depth. The highest clay contents $47 \%$ and $72 \%$ were recorded in profile HIS-P3 respectively for topsoil and subsoil. Whereas sand content was higher in topsoil than in subsoil in profiles HIS-P1 and HIS-P2, the trend in profile HIS-P3 was inconsistent. The silt contents of the studied soils were generally low $(<15 \%)$ throughout the profile depths. According to [33], the textures of profiles HIS-P1 and HIS-P2 are favourable and will not restrict root growth of annual and perennial crops. The heavy clays observed in profile HIS-P3 are likely to restrict root growth of most crop species [33]. The textures also imply difficult workability [9]. Thus for this soil, land preparation should be done when the soil is not extremely dry or wet as the workability would be difficult in extremely dry and wet conditions.

\section{Bulk Density.}

Bulk density (BD) is an important parameter for the description of soil quality and ecosystem function. For example, increases in soil bulk density can reduce the infiltration of water into the soil profile and increase runoff [36]. The topsoil bulk densities of the studied soils ranged from 1.32 to 1.51 $\mathrm{g} / \mathrm{cm}^{3}$ while subsoil bulk densities ranged from 1.43 to $1.71 \mathrm{~g} / \mathrm{cm}^{3}$ for all soil profiles (Table 3 ). With the exception of subsoil BD values of profile HIS-P3, the rest are within the common range for tropical soils [37]. Generally the BD values of the studied soils increase with soil depth, except in profile HIS-P1 in which the trend is not that vivid. Lower bulk densities in topsoils compared to subsoils may be attributed to relatively higher organic carbon content associated with topsoils [38]. According to [39] bulk density is used as a guide to rate soil compaction, porosity, root penetration and soil aeration. It is reported that a normal range of bulk densities for clay is 1.0 to $1.6 \mathrm{~g} / \mathrm{cm}^{3}$ and 1.2 to $1.8 \mathrm{~g} / \mathrm{cm}^{3}$ for sand with potential root restriction occurring at $\geqslant 1.4 \mathrm{~g} / \mathrm{cm}^{3}$ for clay and $\geqslant 1.6 \mathrm{~g} / \mathrm{cm}^{3}$ for sand [40]. The generally high BD values of profile HIS-P3 imply that the soil is compacted and hence plant roots will penetrate the soil with difficulty and movement of air between soil and atmosphere is impaired.

Table 3. Some physical properties of three representative soil profiles of Hombolo Irrigation Scheme, Dodoma Capital City District, Tanzania

\begin{tabular}{llllllll}
\hline Pedons & Horizon & Depth & \multicolumn{3}{l}{ Particle size distribution $\%$} & Textural & Bulk density \\
& & cm & Sand & Silt & Clay & Class & g cm $^{-3}$ \\
\hline HIS-P1 & Ap & $0-14 / 20$ & 69 & 4 & 27 & SCL & 1.51 \\
& BA & $14 / 20-42$ & 56 & 8 & 36 & SC & n.d. \\
& Bt1 & $42-70$ & 59 & 2 & 39 & SC & 1.50 \\
& Bt2 & $70-103$ & 55 & 2 & 43 & SC & 1.56 \\
& Bt3 & $103-137$ & 53 & 2 & 45 & SC & n.d. \\
& BC & $137-170+$ & 63 & 8 & 29 & SCL & n.d. \\
HIS-P2 & Ap & $0-12$ & 71 & 2 & 27 & SCL & 1.32 \\
& C1 & $12-35$ & 53 & 8 & 39 & SC & n.d. \\
& C2 & $35-75$ & 55 & 2 & 43 & SC & 1.43 \\
& C3g1 & $75-137$ & 67 & 2 & 31 & SCL & 1.48 \\
& C4g2 & $137-190+$ & 68 & 7 & 25 & SCL & n.d. \\
HIS-P3 & Ap & $0-10$ & 41 & 12 & 47 & C & 1.51 \\
& B & $10-71$ & 45 & 4 & 51 & hC & 1.62 \\
& Bk & $71-135$ & 19 & 9 & 72 & hC & 1.71 \\
& Ck & $135-160+$ & 47 & 8 & 45 & gSC & n.d. \\
\hline
\end{tabular}

$* \mathrm{SCL}=$ Sand clay loam; $\mathrm{SC}=$ Sand clay; gSC = Gravelly sandy clay; C = Clay; hC = Heavy clay;

n.d. $=$ not determined

\subsection{Soil Chemical Properties}

\section{Soil pH.}

The $\mathrm{pH}$ of the studied soils (Table 4) varied slightly among and within profiles. Topsoil pH ranged 
from 6.5 in profile HIS-P3 to 6.9 in profile HIS-P1, and were rated as slightly acid to neutral respectively according to [5]. Subsoil pH ranged from 5.1 (strongly acid) in profile HIS-P2 to 8.3 (moderate alkaline) in profile HIS-P3 which had $\mathrm{CaCO}_{3}$ in the subsoil. Whereas $\mathrm{pH}_{\mathrm{H} 2 \mathrm{O}}$ increased with depth in profile HIS-P3, there was no definite trend in the other two profiles. $\mathrm{pH}_{\mathrm{KCl}}$ values of all the studied pedons were consistently lower than $\mathrm{pH}_{\mathrm{H} 2 \mathrm{O}}$ values, indicating that the soils had net negative charge [2].

Table 4. Some Chemical Properties of the Studied Soils of Hombolo Irrigation Scheme, Dodoma Capital City District, Tanzania

\begin{tabular}{|c|c|c|c|c|c|c|c|c|c|c|c|c|c|c|c|c|c|c|}
\hline \multirow[t]{3}{*}{ Profile } & \multirow[t]{3}{*}{ Horizon } & \multirow{3}{*}{\begin{tabular}{|l} 
Depth \\
$\mathrm{cm}$
\end{tabular}} & \multicolumn{2}{|l|}{$\mathrm{pH}$} & \multirow{3}{*}{$\begin{array}{l}\mathrm{OC} \\
\%\end{array}$} & \multirow[t]{3}{*}{$\mathrm{OM}$} & \multirow[t]{3}{*}{$\mathrm{N}$} & \multirow{3}{*}{$\frac{\mathrm{C} / \mathrm{N}}{\text { Ratio }}$} & \multirow{3}{*}{\begin{tabular}{|l} 
Avail. $\mathrm{P}$ \\
(Bray1) $\mathrm{mg} / \mathrm{kg}$ \\
$\mathrm{P}$ \\
\end{tabular}} & \multirow{2}{*}{\multicolumn{4}{|c|}{\begin{tabular}{|c} 
Exchangeable bases \\
$\mathrm{cmol}_{(+)} / \mathrm{kg}$
\end{tabular}}} & \multirow{3}{*}{\multicolumn{2}{|c|}{$\frac{\text { TEB }}{\text { CEC }_{\text {soil }}} \mathrm{cmol}_{(+)}$}} & \multirow{3}{*}{$\frac{\mathrm{CEC}_{\text {clav }}}{\mathrm{kg}}$} & \multirow{3}{*}{\begin{tabular}{|l|} 
BS \\
\end{tabular}} & \multirow{3}{*}{\begin{tabular}{|l|}
$\mathrm{EC}$ \\
$\mathrm{dSm}^{-1}$ \\
$1: 2.5$ \\
\end{tabular}} \\
\hline & & & \multirow{2}{*}{$\mathrm{H}_{2} \mathrm{O}$} & \multirow{2}{*}{$\mathrm{KCl}$} & & & & & & & & & & & & & & \\
\hline & & & & & & & & & & $\mathrm{Ca}$ & $\mathrm{Mg}$ & $\mathrm{K}$ & $\mathrm{Na}$ & & & & & \\
\hline \multirow[t]{6}{*}{ HIS-P1 } & Ap & $0-14 / 20$ & 6.9 & 5.9 & 1.1 & 1.81 & 0.11 & 9.5 & 1.1 & 3.7 & 2.6 & 4.1 & 0.6 & 10.9 & 16.6 & 48.1 & 65.7 & 0.63 \\
\hline & BA & $14 / 20-42$ & 7.8 & 7.4 & 0.8 & 1.50 & 0.06 & 14.5 & 0.9 & 1.9 & 2.5 & 2.4 & 0.4 & 7.3 & 16.2 & 36.7 & 44.9 & 0.60 \\
\hline & Bt1 & $42-70$ & 5.7 & 4.6 & 0.7 & 1.14 & 0.05 & 13.2 & 0.2 & 1.8 & 1.6 & 1.2 & 0.3 & 4.9 & 14.8 & 32.1 & 33.4 & 0.44 \\
\hline & Bt2 & $70-103$ & 6.3 & 5.1 & 0.4 & 0.72 & 0.05 & 8.4 & 0.2 & 1.8 & 1.3 & 1.1 & 0.3 & 4.5 & 14.2 & 29.7 & 31.9 & 0.28 \\
\hline & Bt3 & $103-137$ & 6.7 & 5.6 & 0.3 & 0.48 & 0.03 & 9.3 & 0.1 & 1.4 & 1.2 & 0.5 & 0.2 & 3.4 & 13.6 & 28.1 & 25.0 & 0.08 \\
\hline & $\mathrm{BC}$ & $137-170+$ & 7.0 & 6.5 & 0.2 & 0.38 & 0.01 & 22 & 0.1 & 1.3 & 0.9 & 0.5 & 0.2 & 3.0 & 13.0 & 42.2 & 23.0 & 0.02 \\
\hline \multirow[t]{5}{*}{ HIS-P2 } & Ap & $0-12$ & 6.8 & 4.7 & 1.6 & 2.8 & 0.15 & 12.1 & 0.8 & 2.1 & 3.1 & 4.2 & 2.9 & 12.4 & 16.2 & 39.3 & 76.7 & 1.29 \\
\hline & C1 & $12-35$ & 5.1 & 4.6 & 0.7 & 1.29 & 0.07 & 10.7 & 0.5 & 2.1 & 3.1 & 1.3 & 1.5 & 7.9 & 15.6 & 33.4 & 50.8 & 0.82 \\
\hline & $\mathrm{C} 2$ & $35-75$ & 6.0 & 4.7 & 0.4 & 0.61 & 0.04 & 9.0 & 0.4 & 1.2 & 1.3 & 0.6 & 1.4 & 4.5 & 11.2 & 23.2 & 40.4 & 0.54 \\
\hline & C3g1 & $75-137$ & 7.3 & 5.3 & 0.3 & 0.52 & 0.03 & 10 & 0.2 & 0.7 & 1.1 & 0.5 & 1.2 & 3.6 & 7.2 & 19.9 & 49.6 & 0.47 \\
\hline & $\mathrm{C} 4 \mathrm{~g} 2$ & $137-190+$ & 6.8 & 6.3 & 0.2 & 0.39 & 0.01 & 22 & 0.1 & 0.2 & 0.7 & 0.4 & 1.1 & 2.5 & 6.4 & 22.5 & 33.6 & 0.36 \\
\hline \multirow[t]{4}{*}{ HIS-P3 } & Ap & $0-10$ & 6.5 & 5.1 & 1.8 & 3.14 & 0.15 & 10.7 & 1.7 & 5.8 & 9.58 & 2.5 & 17.6 & 35.5 & 90.2 & 178.6 & 76.2 & 4.76 \\
\hline & B & $10-71$ & 7.7 & 6.9 & 0.7 & 1.3 & 0.08 & 9.4 & 0.5 & 9.7 & 12.7 & 4.4 & 19.0 & 45.9 & 77.2 & 146.3 & 83.2 & 2.78 \\
\hline & $\mathrm{Bk}$ & $71-135$ & 8.3 & 7.4 & 0.4 & 0.8 & 0.03 & 15 & 0.3 & 11.5 & 10.2 & 5.1 & 18.6 & 45.2 & 53.9 & 72.6 & 107.6 & 1.81 \\
\hline & $\mathrm{Ck}$ & $135-160+$ & 7.9 & 7.1 & 0.2 & 0.3 & 0.01 & 20 & 0.1 & 7.9 & 6.8 & 4.7 & 14.4 & 33.8 & 50.7 & 111.3 & 118.2 & 0.72 \\
\hline
\end{tabular}

Soil profiles: HIS-P1= Hombolo Irrigation Scheme Profile 1; HIS-P2= Hombolo Irrigation Scheme Profile 2; HISP3= Hombolo Irrigation Scheme Profile 3

Most plants thrive well in soils of $\mathrm{pH} 6.5$ to 7.5 [30]. Thus, HIS-P1 and HIS-P3 soils may present limitations to crop growth because of $\mathrm{pH}$ values $>7.5$ in the subsoil. This may limit availability of some plant nutrients e.g. phosphorus [41].

\section{Organic Carbon and Organic Matter.}

Soil organic carbon is a dynamic soil fraction that has many functions in soils including biological, physical and chemical [33]. The topsoil organic carbon (OC) in the study area ranged from $1.1 \%$ in profile HIS-P1 to $1.8 \%$ in HIS-P3 (Table 4). According to [5] these values are low to medium. Subsoil OC ranged from $0.2 \%$ (in the 3 profiles) to $0.7 \%$ (in profile HIS-P1) corresponding to very low to low values. OC and hence organic matter $(\mathrm{OM})$ decreased with depth in all the studied profiles. The generally low values of $\mathrm{OC} / \mathrm{OM}$ in the study area may be attributed to poor/sparse vegetation due to low rainfall in this semi-arid/arid area where accumulation, decomposition and incorporation of plant residues into the soil is limited.

\section{Available Phosphorus.}

According to [5, 39] all the studied soils had very low available P (Table 4) in both topsoils and subsoils. The low available $\mathrm{P}$ in these soils may be due to $\mathrm{P}$ fixation under alkaline and acid conditions to form insoluble compounds, hence $\mathrm{P}$ becomes sparingly available for plant uptake [41]. The low available $\mathrm{P}$ may also be attributed to the low phosphorus parent materials (granitic rocks) from which the soils were developed. Parent materials influence the entire profile of the $\mathrm{P}$ content and are affected by the weathering process [42]. The observed low phosphorus levels in the study area suggest that the studied soils require $\mathrm{P}$ fertilizer application in form of either organic or inorganic sources for optimum crop production.

Cation Exchange Capacity (CEC), Exchangeable Bases and Base Saturation (BS). 
Cation exchange capacity data are presented in Table 4. According to [43], topsoil CEC values of soil profiles HIS-P1 and HIS-P2 were rated as medium (16.6 and $16.2 \mathrm{cmol}_{(+)} / \mathrm{kg}$ soil respectively), whereas subsoil values were medium $\left(13.0-14.8 \mathrm{cmol}_{(+)} / \mathrm{kg}\right.$ soil) for soil profile HIS-P1 and low to medium (6.4 $15.6 \mathrm{cmol}_{(+)} / \mathrm{kg}$ soil) for soil profile HIS-P2. In the case of soil profile HIS-P3, CEC values were very high throughout the profile depth with values $>40 \mathrm{cmol}_{(+)} / \mathrm{kg}$ soil. The high CEC values may be attributed to the high clay content and the dominance of 2:1 silicate clay minerals [44]. Generally, CEC values decreased with depth in the three soil profiles. The higher CEC values in the topsoils than in subsoils may be attributed to higher soil organic matter in topsoils than in subsoils [45]. Calculated values of CEC of clay are also presented in Table 4. The high $\mathrm{CEC}_{\text {clay }}$ values $\left(72.6-178.6 \mathrm{cmol}_{(+)} / \mathrm{kg}\right.$

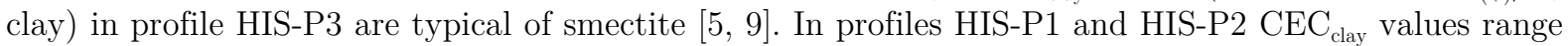
from about $20-48 \mathrm{cmol}_{(+)} / \mathrm{kg}$ clay reflecting more of mixed clay mineralogy [11].

Exchangeable bases ( $\mathrm{Ca}, \mathrm{Mg}, \mathrm{K}$ and $\mathrm{Na}$ ) in the studied soils are presented in Table 4. Exchangeable calcium levels varied among and within profiles. According to [5, 39] topsoil Ca in profile HIS-P1 was high $\left(3.7 \mathrm{cmol}_{(+)} / \mathrm{kg}\right.$ soil) whereas subsoil Ca was medium $\left(1.3-1.9 \mathrm{cmol}_{(+)} / \mathrm{kg}\right.$ soil $)$. In profile HIS-P2 topsoil Ca was medium $\left(2.1 \mathrm{cmol}_{(+)} \mathrm{kg}\right.$ soil $)$ whereas subsoil Ca ranged from low to medium $(0.2-2.1$ $\mathrm{cmol}_{(+)} / \mathrm{kg}$ soil). In profile HIS-P3 topsoil Ca was rated as medium $\left(5.8 \mathrm{cmol}_{(+)} / \mathrm{kg}\right.$ soil) while it was medium to high $\left(7.9-11.5 \mathrm{cmol}_{(+)} / \mathrm{kg}\right.$ soil $)$.

Topsoil exchangeable $\mathrm{Mg}$ was rated as medium $\left(2.6 \mathrm{cmol}_{(+)} / \mathrm{kg}\right.$ soil $)$ in profile HIS-P1 while subsoil values were low to medium $\left(0.9-2.5 \mathrm{cmol}_{(+)} / \mathrm{kg}\right.$ soil). In profile HIS-P2 topsoil exchangeable Mg was high $\left(3.1 \mathrm{cmol}_{(+)} / \mathrm{kg}\right.$ soil) while subsoil $\mathrm{Mg}$ values ranged from low to high $\left(0.7-3.1 \mathrm{cmol}_{(+)} / \mathrm{kg}\right.$ soil $)$. Profile HIS-P3 had very high exchangeable $\mathrm{Mg}$ with values $>6.0$ throughout the profile depth. [46] reported that 0.2 to $0.64 \mathrm{cmol}_{(+)} / \mathrm{kg}$ soil levels of exchangeable magnesium are sufficient for most crops. Therefore, soils of the study area have sufficient levels of exchangeable $\mathrm{Mg}$ for crop production.

Exchangeable $\mathrm{K}$ values in the three studied soils were generally very high. In profile HIS-P1 topsoil exchangeable $\mathrm{K}$ was $4.1 \mathrm{cmol}_{(+)} / \mathrm{kg}$ soil and rated as very high, whereas subsoil values ranged from 0.5 $2.4 \mathrm{cmol}_{(+)} / \mathrm{kg}$ soil (medium to very high). In profile HIS-P2 topsoil $\mathrm{K}$ was very high $\left(4.2 \mathrm{cmol}_{(+)} / \mathrm{kg}\right.$ soil) whereas subsoil values ranged from medium to high $\left(0.4-1.3 \mathrm{cmol}_{(+)} / \mathrm{kg}\right.$ soil). In profile HIS-P3 exchangeable $K$ was very high throughout the profile with values of $2.5 \mathrm{cmol}_{(+)} / \mathrm{kg}$ for topsoil and 4.4 $5.1 \mathrm{cmol}_{(+)} / \mathrm{kg}$ soil for subsoil. From these results the studied soils have more than adequate levels of exchangeable potassium. The main source of $\mathrm{K}$ for plants growing under natural conditions is the weathering of $\mathrm{K}$ minerals and organic K-sources such as composts and plant residues [47].

Topsoil exchangeable $\mathrm{Na}$ in profile HIS-P1 was rated as medium $\left(0.6 \mathrm{cmol}_{(+)} / \mathrm{kg}\right.$ soil $)$ whereas subsoil $\mathrm{Na}$ ranged from low to medium $\left(0.2-0.4 \mathrm{cmol}_{(+)} / \mathrm{kg}\right.$ soil). In profile HIS-P2 exchangeable Na values were very high $\left(2.9 \mathrm{cmol}_{(+)} / \mathrm{kg}\right.$ soil $)$ and high $\left(1.1-1.5 \mathrm{cmol}_{(+)} / \mathrm{kg}\right.$ soil $)$ respectively in topsoil and subsoil. In profile HIS-P3 exchangeable $\mathrm{Na}$ was very high [39] throughout the profile with values of 17.6 $\mathrm{cmol}_{(+)} / \mathrm{kg}$ soil for topsoil and $14.4-19.0 \mathrm{cmol}_{(+)} / \mathrm{kg}$ soil for subsoil. In general terms, the high levels of exchangeable $\mathrm{K}$ and $\mathrm{Na}$ suggest that these nutrients may probably cause nutrient imbalance and affect nutrient availability [48]. The high levels of exchangeable Na particularly in profile HIS-P3 are likely to cause a problem of sodicity in the soil [5].

Base saturation (BS) values of the studied soils are presented in Table 4. Topsoil BS values of the three studied profiles are high $(>50 \%)$ implying good soil fertility for crop production. The BS values in profiles HIS-P1 and HIS-P2 decrease with depth while in profile HIS-P3 the values increase with depth and are high throughout the profile depth. When all the soil particle exchange sites are occupied with bases, the BS becomes 100\%. This happens when the soil pH is well above 7 (alkaline). It is reported that when the soil $\mathrm{pH}$ is above 7.2 , there is free solution $\mathrm{Ca}, \mathrm{Mg}$, and/or $\mathrm{Na}$ (unattached to the soil exchange complex) in the soil that is unavoidably extracted. Then the sum of the measured cation saturations could add up to more than 100\% [49]. This is the reason for the high BS above 100\% in profile HIS-P3 which indicates that the soil is highly alkaline.

Electrical Conductivity.

Data on electrical conductivity (EC) of the studied soils are presented in Table 4. The EC values of soil profiles HIS-P1 and HIS-P2 were $<1.7 \mathrm{dS} / \mathrm{m}$ throughout their profile depths. Such values of EC pose no threat at all on of crop yields. However, EC values of the upper three horizons of profile HIS-P3 were $>1.7 \mathrm{dS} / \mathrm{m}$ with values of $4.76,2.78$ and $1.81 \mathrm{dS} / \mathrm{m}$ from topsoil down the profile. Such values are likely to cause at least $25 \%$ yield reduction of most crops [5].

Extractable Micronutrients. 
Extractable micronutrient levels are presented in Table 5. Extractable Zn of the soils across the horizons in profile HIS-P1 ranged from $0.28 \mathrm{mg} / \mathrm{kg}$ to $0.56 \mathrm{mg} / \mathrm{kg}$ in subsoil and topsoil respectively. In profile HIS-P2 extractable Zn levels ranged from $0.04 \mathrm{mg} / \mathrm{kg}$ in subsoil to $0.69 \mathrm{mg} / \mathrm{kg}$ in topsoil, which are rated as very low to low respectively, while in profile HIS-P3 extractable Zn ranged from $0.24 \mathrm{mg} / \mathrm{kg}$ in subsoil to $0.75 \mathrm{mg} / \mathrm{kg}$ in topsoil and rated as very low to low respectively [39, 50]. The levels of Zn in the study area showed decreasing trend with increasing depth in profiles HIS-P2 and HIS-P3, but not in profile HIS-P1 which had no clear trend. The low values of $\mathrm{Zn}(<1 \mathrm{mg} / \mathrm{kg})$ in the study area could be attributed to high degree of weathering (particularly in profile HIS-P1), Zn nutrient mining by crops for long time without $\mathrm{Zn}$ replenishment, and/or low inherent $\mathrm{Zn}$ content of the soil parent materials which together may result into low yields and nutritive quality of crops grown in the study area [51].

In profile HIS-P1, extractable Mn values ranged from $4.8 \mathrm{mg} / \mathrm{kg}$ (high) to $45.6 \mathrm{mg} / \mathrm{kg}$ (very high) in subsoil and topsoil respectively. In profile HIS-P2, Mn levels ranged from $1.29 \mathrm{mg} / \mathrm{kg}$ (medium) to 45.6 $\mathrm{mg} / \mathrm{kg}$ (very high) respectively in subsoil and topsoil. In the case of profile HIS-P3, Mn levels ranged from $2.1 \mathrm{mg} / \mathrm{kg}$ (medium) to $16.4 \mathrm{mg} / \mathrm{kg}$ (very high) in subsoil and topsoil respectively. Generally Mn levels tended to decrease with depth in all the three soil profiles. According to [39, 50] the extractable Mn levels of the studied soils are sufficient $\left(>1.5 \mathrm{mgkg}^{-1}\right)$ implying that they have adequate amount of Mn for crop production.

Extractable Fe levels in profile HIS-P1 ranged from $3.3 \mathrm{mg} / \mathrm{kg}$ (low) in subsoil to $7.1 \mathrm{mg} / \mathrm{kg}$ (high) in topsoil. In profile HIS-P2, Fe levels were rated as very high for both subsoil and topsoil with values ranging from $18.8 \mathrm{mg} / \mathrm{kg}$ to $29.1 \mathrm{mg} / \mathrm{kg}$ respectively. In profile HIS-P3, Fe values ranged from 1.95 $\mathrm{mg} / \mathrm{kg}$ (very low) to $3.25 \mathrm{mg} / \mathrm{kg}$ (low) [50]. The Fe values showed no clear trend with increasing depth except in profile HIS-P1 in which the levels tended to decrease with increasing depth.

Extractable $\mathrm{Cu}$ levels in profile HIS-P1 ranged from $1.21 \mathrm{mg} / \mathrm{kg}$ to $1.63 \mathrm{mg} / \mathrm{kg}$ in subsoil and 1.63 $\mathrm{mg} / \mathrm{kg}$ in topsoil and were rated as high across the profile. In profile HIS-P2 the Cu levels ranged from $1.01 \mathrm{mg} / \mathrm{kg}$ in subsoil to $1.94 \mathrm{mg} / \mathrm{kg}$ in topsoil and rated as high across the profile. Also in profile HIS$\mathrm{P} 3$ the $\mathrm{Cu}$ levels ranged from $1.63 \mathrm{mg} / \mathrm{kg}$ in subsoil to $1.83 \mathrm{mg} / \mathrm{kg}$ in topsoil and similarly rated as high across the profile. According to [39] the extractable $\mathrm{Cu}$ levels of the studied soils were rated as sufficient $(>0.75 \mathrm{mg} / \mathrm{kg})$. Hence the soils have adequate amounts of extractable $\mathrm{Cu}$ for crop production [52].

Table 5. Micronutrients' status of the soils of Hombolo Irrigation Scheme, Dodoma Capital City District, Tanzania

\begin{tabular}{clcccc}
\hline Pedons & Horizon & \multicolumn{3}{c}{ Extractable Micronutrients $(\mathrm{mg} / \mathrm{kg})$} \\
& & $\mathrm{Zn}$ & $\mathrm{Mn}$ & $\mathrm{Fe}$ & $\mathrm{Cu}$ \\
\hline HIS-P1 & Ap & 0.56 & 45.58 & 7.12 & 1.63 \\
& BA & 0.40 & 23.81 & 8.42 & 1.63 \\
& Bt1 & 0.28 & 17.07 & 6.48 & 1.21 \\
& Bt2 & 0.32 & 6.73 & 3.25 & 1.32 \\
& Bt3 & 0.32 & 4.83 & 3.25 & 1.21 \\
& BC & 0.28 & 17.62 & 3.25 & 1.73 \\
& Ap & 0.69 & 45.58 & 29.10 & 1.94 \\
& C1 & 0.79 & 40.14 & 18.76 & 2.25 \\
& C2 & 0.36 & 4.83 & 49.77 & 1.94 \\
& C3g1 & 0.32 & 1.29 & 54.94 & 1.42 \\
& C4g2 & 0.04 & 15.99 & 27.16 & 1,01 \\
& Ap & 0.75 & 16.42 & 3.25 & 1.83 \\
& BIS-P3 & 0.48 & 7.8 & 3.89 & 1.73 \\
& Bk & 0.56 & 3.20 & 3.25 & 2.25 \\
& Ck & 0.24 & 2.11 & 1.95 & 1.63 \\
\hline HIS-P1= Soil Profile 1 & HIS-P2 = Soil Profile 2 & HIS-P3 = Soil Profile 3 &
\end{tabular}

\subsection{Soil Classification}

Soil morphological, physical and chemical properties were used to define the diagnostic horizons and other features for classification of the soils. Tables 6 and 7 present summaries of diagnostic horizons and 
features of the studied soils and their corresponding taxa up to the family level of the Soil Taxonomy [12]) and up to Tier-2 of the FAO World Reference Base Classification Scheme [13].

Table 6. Summary of morphological and diagnostic features of the studied soils and classification according to USDA Soil Taxonomy [12]

\begin{tabular}{|c|c|c|c|c|c|c|c|c|c|c|}
\hline Pedons & $\begin{array}{l}\text { Diagnostic } \\
\text { epipedon ar } \\
\text { subsurface } \\
\text { horizon }\end{array}$ & & \multicolumn{2}{|c|}{ Other diagnostic features } & \multicolumn{2}{|c|}{ Order } & Suborder & Greatgroup & Subgroup & Family \\
\hline HIS-P1 & $\begin{array}{l}\text { Ochric } \\
\text { epipedon, } \\
\text { Argillic } \\
\text { horizon }\end{array}$ & & \multicolumn{2}{|c|}{$\begin{array}{l}\text { Gently sloping (slope } 4 \% \text { ), } \\
\text { very deep, clayey, slightly } \\
\text { acid, aridic - ustic SMR, } \\
\text { isohyperthermic STR }\end{array}$} & \multicolumn{2}{|c|}{ Ultisols } & Ustults & Rhodustults & $\begin{array}{l}\text { Typic } \\
\text { Rhodustults }\end{array}$ & $\begin{array}{l}\text { Gently sloping, very } \\
\text { deep, clayey, slightly } \\
\text { acid, isohyperthermic, } \\
\text { Typic Rhodustults }\end{array}$ \\
\hline HIS-P2 & $\begin{array}{l}\text { Ochric } \\
\text { epipedon, } \\
\text { Cambic } \\
\text { horizon }\end{array}$ & & \multicolumn{2}{|c|}{$\begin{array}{l}\text { Gently sloping (slope } 4 \% \text { ), } \\
\text { very deep, clayey over } \\
\text { loamy, slightly acid to } \\
\text { neutral, aridic (in places } \\
\text { aquic SMR), } \\
\text { isohyperthermic STR }\end{array}$} & \multicolumn{2}{|c|}{ Inceptisols } & Ustepts & Dystrustepts & $\begin{array}{l}\text { Fluventic } \\
\text { Dystrustepts }\end{array}$ & $\begin{array}{l}\text { Gently sloping, very } \\
\text { deep, loamy, slightly } \\
\text { acid to neutral, } \\
\text { isohyperthermic, } \\
\text { Fluventic Dystrustepts }\end{array}$ \\
\hline HIS-P3 & $\begin{array}{l}\text { Ochric } \\
\text { epipedon, } \\
\text { Calcic hori }\end{array}$ & & \multicolumn{2}{|c|}{$\begin{array}{l}\text { Gently sloping (slope } 3 \% \text { ), } \\
\text { very deep, clayey, aridic - } \\
\text { ustic SMR, moderately } \\
\text { alkaline, isohyperthermic } \\
\text { STR, deep wide cracks, } \\
\text { wedge-shaped aggregates, } \\
\text { slickensides, gilgai micro- } \\
\text { relief }\end{array}$} & \multicolumn{2}{|c|}{ Vertisols } & Torrerts & Calcitorrerts & $\begin{array}{l}\text { Chromic } \\
\text { Calcitorrerts }\end{array}$ & $\begin{array}{l}\text { Gently sloping, very } \\
\text { deep, clayey, } \\
\text { moderately alkaline, } \\
\text { isohyperthermic, } \\
\text { Chromic Calcitorrerts }\end{array}$ \\
\hline \multicolumn{11}{|c|}{$\begin{array}{l}\text { HIS-P1 = Soil profile } 1 \text { HIS-P2 = Soil profil } \\
\text { Table 7. Summary of morphological and diag } \\
\text { World Reference Base for Soil Resources [13] }\end{array}$} \\
\hline Pedons & $\begin{array}{l}\text { Diagnostic } \\
\text { horizons }\end{array}$ & & $\begin{array}{l}\text { her diagnostic } \\
\text { tures/ materials }\end{array}$ & $\begin{array}{l}\text { Prefix } \\
\text { Quali }\end{array}$ & & Suffix & Qualifiers & $\begin{array}{l}\text { Reference Soi } \\
\text { (RSG) - TIEI }\end{array}$ & $\begin{array}{l}\text { il Group } \\
\text { R1 }\end{array}$ & WRB soil name - TIER 2 \\
\hline HIS-P1 & Argic & Pres & esence of clay cutans & $\begin{array}{l}\text { Hapli } \\
\text { Cutal }\end{array}$ & & $\begin{array}{l}\text { Hyper } \\
\text { Profor }\end{array}$ & $\begin{array}{l}\text { dystric, } \\
\text { adic, Rhodic }\end{array}$ & Acrisols & & $\begin{array}{l}\text { Haplic Cutanic Acrisols } \\
\text { (Hyperdystric, Profondic, } \\
\text { Rhodic) }\end{array}$ \\
\hline HIS-P2 & Cambic & & $\begin{array}{l}\text { esence of sesquioxide } \\
\text { ttles }\end{array}$ & Hapli & & Dystri & ic, Oxyaquic & Cambisols & & $\begin{array}{l}\text { Haplic Cambisols (Dystric, } \\
\text { Oxyaquic) }\end{array}$ \\
\hline HIS-P3 & $\begin{array}{l}\text { Vertic, } \\
\text { calcic }\end{array}$ & & $\begin{array}{l}\text { nkensides, cracks, } \\
\text { dge shaped aggregates, } \\
\text { gai microrelief }\end{array}$ & $\begin{array}{l}\text { Mazi } \\
\text { Calci }\end{array}$ & & $\begin{array}{l}\text { Calcar } \\
\text { Hyper }\end{array}$ & $\begin{array}{l}\text { ric, } \\
\text { eutric }\end{array}$ & Vertisols & & $\begin{array}{l}\text { Calcic Mazic Vertisols } \\
\text { (Calcaric, Hypereutric) }\end{array}$ \\
\hline
\end{tabular}

HIS-P1 = Soil profile $1 \quad$ HIS-P2 = Soil profile $2 \quad$ HIS-P3 = Soil profile 3

\section{Conclusions and Recommendations}

\subsection{Conclusions}

The following conclusions can be drawn from the results of the study:

1. All studied soils had optimum depth, texture, consistence, workability and root penetrability for a wide range of crop production. The landscape of the area with gentle slope and soils studied are favourable for mechanization except the heavy textured soil. 
2. Climatic conditions of the area (being semi-arid to arid) and hence moisture regimes of the studied soils pose a serious limitation to crop production.

3. The soils of the study area are of low to medium soil fertility because of low N, high and too low $\mathrm{pH}$, low available $\mathrm{P}$, low $\mathrm{Zn}$ and $\mathrm{Ca}$ in all three soils, medium levels of CEC. Hence the use of $\mathrm{N}$ and P fertilizers with Ca and Zn fertilization will improve crop yields and quality significantly.

4. The soils of Hombolo irrigation scheme which represent soils of Dodoma Capital City District classified according to the USDA Soil Taxonomy and FAO-WRB for Soil Resources respectively as:

(i) Typic Rhodustults [(Haplic CutanicAcrisols (Hyperdystric, Profondic, Rhodic)] for red soils (Profile HIS-P1),

(ii) Fluventic Dystrustepts [(Haplic Cambisols (Dystric, Oxyaquic)] (Profile HIS-P2) and

(iii) Chromic Calcitorrerts [(Calcic Mazic Vertisols (Calcaric, Hypereutric)]for black heavy textured mbuga soil (Profile HIS-P2)

\subsection{Recommendations}

The following recommendations are made with respect to land use of the studied area:

1. Sustainable crop production in the study area will be achieved through the use of technologies suitable for improving soil fertility such as manuring, crop rotation, proper management of crop residues, fallow periods, and introduction of leguminous cover crops in the farming system and use of fertilizers especially acidified types of fertilizers due to alkaline (high $\mathrm{pH}$ ) condition of the study soils.

2. Use of technologies such as early planting, planting at different times, farm-yard manure application, intercropping, use of drought resistant crops are inevitable in view of climatic and soil conditions of the study area.

3. Due to poor soil fertility of the study area, it is evident that soils will respond to mineral and organic fertilizer application. Therefore, further research should be carried out in order to assess efficient use, types and application rates of these fertilizers.

Acknowledgements. The authors acknowledge the Innovative Agricultural Research Initiative (iAGRI) programme of Sokoine University of Agriculture, Morogoro, Tanzania for the funding that supported this research work.

\section{References}

1. R. F. Breimer, A.J. van Kekem and H. Reuler, "Guidelines for soil survey and land evaluation in ecological research." UNESCO (Paris and New York), 124 pages, 1986.

2. B.M. Msanya, J.A. Munishi, N. Amuri, E. Semu, L. Mhoro, and Z. Malley, "Morphology, Genesis, Physicochemical Properties, Classification and Potential of Soils Derived from Volcanic Parent Materials in Selected Districts of Mbeya Region, Tanzania." International Journal of Plant and Soil Science, vol. 10 no. 4, pp. 1-19, 2016.

3. D. Dent and A. Young, "Soil survey and land evaluation." George Allen and Unwin, London, 278 pages, 1981.

4. P. Uwitonze, B.M. Msanya, P.W. Mtakwa, S. Uwingabire, and S. Sirikare, "Pedological Characterization of Soils Developed from Volcanic Parent Materials of Northern Province of Rwanda."

Agriculture, Forestry and Fisheries vol. 5 no. 6, pp. 225-236, 2016.

5. B.M. Msanya, D.N. Kimaro, G.G. Kimbi, E.P. Kileo and J.D.J. Mbogoni, "Land resource inventory and suitability assessment for the major land use types in Morogoro Urban District, Tanzania." Soil and Land Resources of Morogoro Rural and Urban Districts, vol. 4, Department of Soil Science, Sokoine University of Agriculture, Morogoro Tanzania, 78 pages, 2001

6. J. Munishi, "Pedological characterisation and assessment of agricultural potential of soils of selected districts of Mbeya Region, Tanzania." MSc dissertation, Department of Soil Scince, Sokoine University of Agriculture, Morogoro, Tanzania, 136 pages, 2012.

7. M. Baba, F.W. Hennie, E. Soehady and T. Sanudin, "Geochemical characterization of volcanic soils from Tawau, Sabah." Geological Society of Malaysia Bulletin, vol. 54, pp. 33-36, 2008. 
8. N.K. Moustakas and F. Georgoulias, "Soils developed on volcanic materials in the island of Thera, Greece." Geoderma vol. 129, pp. 125-138, 2005.

9. T. Mwasyika, "Influence of soil fertility on mineral nutritive quality of cereals and vegetables grown on typical soils of Dodoma Capital District, Tanzania." MSc dissertation, Department of Soil Science, Sokoine University of Agriculture, Morogoro, Tanzania, 135 pages, 2015.

10. E. De Pauw, "Soils, physiography and agroecological zones of Tanzania." Ministry of Agriculture and Food and Agriculture Organization (FAO), Dar es Salaam, 1984.

11. B.M. Msanya, A.K. Kaaya, A. Shigeru, O. Hiroo and G.I. Nyadzi, "Pedological characteristics, general fertility and classification of some benchmark soils of Morogoro District, Tanzania." African Journal of Science and Technology (AJST), Science and Engineering Series, vol. 4, no. 2, pp. 101-112, 2003.

12. Soil Survey Staff, "Keys to Soil Taxonomy." Twelfth Edition, United States Department of Agriculture, Natural Resources Conservation Service, 359 pages, 2010.

13. FAO-WRB, "World Reference Base for Soil Resources." A framework for international classification, correlation and communication, World Soil Resources reports 103, pp. 145-159, (2006).

14. K. Sandstrom, "Forest and water - friends or foes? Hydrological implications of deforestation and land degradation in semi-arid Tanzania." PhD. thesis, Linkoping studies in Arts and Science 120, Linkoping University, S- 581-83 Linkoping, Sweden, 69 pages + 6 supporting manuscripts, 1995.

15. R.A. Rwebugisa, "Groundwater recharges assessment in the Makutupora Basin, Dodoma, Tanzania." Master of Science Thesis in Geo-Information Science and Earth Observation, International Institute for Geo-Information Science and Earth Observation, Enschede, The Netherlands, 2008.

16. F.B. Wade and F. Oates, "An explanation of the Degree Sheet No. 52, Dodoma." Geological Survey of Tanganyika, Short paper, vol. 17, pp.1-60, 1938.

17. D.J. Pratt and M.D. Gwynne, "Rangeland Management and Ecology in East Africa." Hodder and Stoughton Publishers, London, UK, 30 pages, 1977.

18. FAO, "Guidelines for soil description." 4th edition, Food and Agriculture Organization of the United Nations, Rome, 77 pages, 2006.

19. National Soil Service, "Laboratory procedures for routine analysis." $3^{\text {rd }}$ edition, Agricultural Research Institute, Mlingano Tanga, Tanzania, 1990.

20. USDA, "Soil Taxonomy. A Basic System of Soil Classification for Making and Interpreting Soil Surveys." U.S. Dept. of Agric. Handbook 436, U.S. Govt. Printing Office. Washington, DC, 754 pages, 1975.

21. E.O. McLean, "Soil pH and lime requirement. In: Methods of soil analysis." Part 2, Agronomy Monograph No.9 (Edited by A.L. Page, R.H. Miller, and D.R. Keeney), American Society of Agronomy, Madison Wisconsin, pp. 199-224, 1986.

22. D.W. Nelson and L.E. Sommers, "Organic carbon in soils." In: Methods of Soil Analysis." Part 2, Agronomy Monograph No.9 (Edited by A.L. Page, R.H. Miller, and D.R. Keeney), American Society of Agronomy, Madison Wisconsin. pp. 570-571, 1982

23. E.K. Duursma and R. Dawson (Eds), "Marine organic chemistry: Evolution, composition, interactions and chemistry of organic matter in seawater." Elsevier, Amsterdam, 521 pages, 1981.

24. J.M. Bremner and C.S. Mulvaney, "Total Nitrogen." In: Methods of Soil Analysis. Part 2, Agronomy, Monograph No.9 (Edited by A.L. Page, R.H. Miller and D.R. Keeney), American Society of Agronomy, Madison Wisconsin, pp. 149-157, 1982.

25. R.H. Bray and L.T. Kurtz, "Determination of total, organic and available forms of phosphorus in soils." Soil Science, vol. 58, pp. 39-45, 1945.

26. J. Murphy and I.P. Riley, "A modified single solution method for the determination of phosphate in natural waters." Anal. Chim. Acta, vol. 27, pp. 31-36, 1962.

27. F.S. Watanabe and S.R. Olsen, "Test of an ascorbic acid method for determining phosphorus in Central Illinois." Midwest Friends of the Pleistocene $26^{\text {th }}$ Field Conf., Campaign, IL, Illinois Geological Survey Guidebook 13, pp. 129-134, 1965

28. W.L. Lindsay and W.A. Norvell, "Development of DTPA soil test for zinc, iron, manganese, and copper." Soil Science Society of America Journal, vol. 42, pp. 421-428, 1978. 
29. H.D. Chapman, "Cation Exchange Capacity." In: Methods of Soil Analysis. Part 1, $1^{\text {st }}$ edition, Agronomy Monograph no. 6, (Edited by C.A. Black), American Society of Agronomy, Madison, Wisconsin, vol. 9, pp. 891901, 1965.

30. D. Baize, "Soil science analysis. A guide to correct use." John Wiley and Sons Ltd., West Sussex, 192 pages, 1993.

31. G.W. Thomas, "Exchangeable cations." In: Methods of Soil Analysis. Part 2, Agronomy Monograph No.9, (Edited by A.L. Page, R.H. Miller and D.R.) Keeney, American Society of Agronomy, Madison Wisconsin, pp. 149-157, 1982.

32. J. Moberg, "Soil and Plant Analysis Manual." The Royal Veterinary and Agricultural University, Chemistry Department, Copenhagen, Denmark, 133 pages, 2000.

33. K.I. Peverill, L.A. Sparrow and D.J. Reuter, (Editors), "Soil analysis - an Interpretation Manual." CSIRO Publishing, Australia, 369 pages, 1999.

34. I.H. Massawe, B.M. Msanya and F.B. Rwehumbiza, "Pedological Characterization and Fertility Evaluation of Paddy Soils of Mvumi Village, Kilosa District, Tanzania." International Journal of Current Research in Biosciences and Plant Biology, vol. 4, no. 4, pp. 49-60, 2017.

35. H.R. Mbaga, B.M. Msanya and J.P. Mrema, "Pedological Characterization of Typical Soil of Dakawa Irrigation Scheme, Mvomero District, Morogoro Region, Tanzania." International Journal of Current Research in Biosciences and Plant Biology, vol. 4, no. 6, pp. 77-86, 2017.

36. R.J. Gregory, S. Schwercanning, T.W. Lee and J.C. Wise, "Cognitive bibliotherapy for depression: A metaanalysis." Professional Psychology: Research and Practice, vol. 35, pp. 275-280, 2006.

37. S.V. Zonn, "Tropical and subtropical soil science." Mir Publisher, Moscow, 422 pages, 1986.

38. R. Dalal and R.J. Meyer, "Long term trend in fertility of soils under continuous cultivation and cereal cropping in Queensland. II. Total organic carbon and its rate of loss from soil profile." Australian Journal of Soil Research, vol. 24, pp. 301-309, 1986.

39. J.R. Landon (editor), "Booker Tropical Soil Manual. A handbook for soil survey and agricultural land evaluation in the tropics and subtropics." Longman Scientific and Technical Publishers, Essex. 474 pages, 1991.

40. H.P Cresswell and G.J. Hamilton, "Particle Size Analysis." In: Soil Physical Measurement and Interpretation for Land Evaluation, (Eds. N.J. McKenzie, H.P. Cresswell and K.J. Coughlan), CSIRO Publishing, Collingwood, Victoria, pp. 224-239, 2002.

41. P. Marschner, "Marschner's mineral nutrition of higher plants." Amsterdam, The Netherlands Academic Press, 651 pages, 2012.

42. J. Romanya and P. Rovira, "Organic and inorganic $\mathrm{P}$ reserves in rain-fed and irrigated calcareous soils under long-term organic and conventional agriculture." Geoderma, vol. 151, pp. 378-386, 2009.

43. EUROCONSULT, "Agriculture compendium for rural development in the tropics and subtropics: $3^{\text {rd }}$ revised edition." Elsevier, Amsterdam, Oxford, New York, Tokyo, 740 pages, 1989.

44. S.M. Sharami, A. Forghani, A. Akbarzadeh and H. Ramezanpour, "Mineralogical characteristics and related surface charge fluctuations of some selected soils of temperate regions of northern Iran." Clay Minerals, vol. 45, no. 3, pp. 327-348, 2010.

45. M.K.A. Adeboye, A. Bala, A.O. Osunde, A.O. Uzoma, A.J. Odofin and B.A. Lawal, "Assessment of soil quality using soil organic carbon and total nitrogen and microbial properties in tropical agroecosystems." Agricultural Sciences, vol. 2, pp. 34-40, 2011.

46. A. Samadi, "Potassium Exchange Isotherms as Plant Availability Index in Selected Calcareous Soils of Western Azarbaijan Province, Iran." Turk Journal Agric For, vol. 30, pp. 213-222, 2006.

47. K. Tazaki, "Green-tuff landslide areas are beneficial for rice nutrition in Japan." Annals of the Brazilian Academy of Sciences, vol. 78, no. 4, pp. 749-763, 2006.

48. J.J. Tenga, B.M. Msanya, J.M. Semoka, E. Semu and S.B. Mwango, "Pedological Characterization and Classification of Some Typical Soils in Three Agro-Ecological Settings of South-Eastern Tanzania." International Journal of Scientific \& Engineering Research, vol. 9, no. 2, pp. 692-702, 2018.

49. AgVita Analytical, "Cation Exchange Capacity." Available: http://www.agvita.com.au/pdf/expresssoil/ expressSoil_CEC.pdf

50. M.R. Motsara and R.N. Roy, "Guide to Laboratory establishment for plant nutrient analysis." FAO Fertilizer and Plant nutrition bulletin, Food and Agriculture Organization, Rome, 219 pages, 2008. 
51. W.H. Alloway, "Soil-plant-animal and human interrelationships in trace element nutrition." In Trace Elements in Human and Animal Nutrition, Ed. W. Mertz, pp. 465-488, Academic Press, Orlando, San Diego, New York, Austin, London, Montreal, Sydney, Tokyo, Toronto, 1986.

52. X.J. Wang and J.S Chen, "Trace element contents and correlation in surface soils in China's eastern alluvial plains." Environ. Geol., vol. 36, pp. 277-284, 1998. 